\title{
CHALLENGES IN RAISING CREDIT: A STUDY OF MSMES IN BHOPAL DISTRICT
}

\author{
Sourabh Saraiya \\ Research Scholar, LNCT University, Bhopal, Madhya Pradesh, India \\ Dr. Kul Prakash \\ Associate Professor, LNCT University, Bhopal, Madhya Pradesh, India
}

\begin{abstract}
Indian Economy is dominated by vibrant set of Enterprises which are prestigiously known as Micro Small Medium Enterprises (MSME) for their scale of Operations. The role of MSME'S in economic and social development of country is widely acknowledged. They are nurseries for entrepreneurship often driven by individual creativity, innovation and make significant contribution to Country's GDP, Manufacturing Output, Exports and Employment Generation. Despite of this sector's inherent capabilities, MSMEs in India are facing number of problems and raising credit has become their major problem. The aim of the paper is to study about various challenges and issues faced by Indian MSME. The research is conducted after collecting data from 200 MSME Unit from Bhopal by taking their interview with the help of structured questionnaire. Also the questionnaire was administered to 50 Branch Manager/Field Officers/Credit Officers of different banks dealing with MSME financing and main constraint observed by each of them has been analyzed The study indicated that Non/Inadequate/delayed availability of credit, Complex Loan Process, high Collateral security, high interest rates and Non Cooperative attitude of bank employee are key challenges faced by MSME in raising finance.
\end{abstract}

Key Words: MSMEs, Credit, Challenges, Financing Constraints

Cite this Article: Sourabh Saraiya and Kul Prakash, Challenges in Raising Credit: A Study of MSMEs in Bhopal District, International Journal of Management, 11(12), 2020, pp 3177-3185.

http://iaeme.com/Home/issue/IJM?Volume $=11 \&$ Issue $=12$

\section{INTRODUCTION}

MSME (Micro, Small and Medium Enterprises) is a part of Indian Economy and it's managed by the Indian Government. Rules and Regulation regarding MSME is framed by Indian Government. MSME is that kind of sector which grows faster and helps the economy for its faster development. MSME helps in industrializing the rural areas by providing lot of business 
opportunities with low budget of investment. It also helps in socio- economic development of the nation.

Basically, the industries are classified under the MSME development act, 2006, into two types:

- Enterprises engaged in the production or Manufacturing of the Product.

- Enterprises engaged in Providing Services.

Table 1 Definition of MSME with effect from 01.072020

\begin{tabular}{|c|c|}
\hline Micro enterprises & $\begin{array}{c}\text { where the investment in Plant and Machinery or Equipment does } \\
\text { not exceed one crore rupees and turnover does not exceed five } \\
\text { crore rupees; }\end{array}$ \\
\hline Small enterprises & $\begin{array}{c}\text { where the investment in Plant and Machinery or Equipment does } \\
\text { not exceed ten crore rupees and turnover does not exceed fifty } \\
\text { crore rupees }\end{array}$ \\
\hline Medium enterprises & $\begin{array}{c}\text { where the investment in Plant and Machinery or Equipment does } \\
\text { not exceed fifty crore rupees and turnover does not exceed two } \\
\text { hundred and fifty crore rupees }\end{array}$ \\
\hline
\end{tabular}

\subsection{Research Objectives}

To identify key Challenges faced by MSME's in raising credit in Bhopal District

\section{LITERATURE REVIEW}

Ramachandra (2001) in his article, "Reviving Sick Units," has observed that financial problem has a root cause For sick small industrial unit for which the public sector bank and the government should provide need based Financial, technology, management

John and Stephen (2004) in "The SMEs Financing Gap: Theory and Evidence," point out that SMEs

Financing gaps result from sources like lack of proper financing mechanism-with gaps in legal framework. The banks may avoid financing start - ups and young firms which lack collaterals and offer high returns but high risk. The critical determinants of SMEs access to finance are macroeconomic, legal, regulatory and financial framework.

Mehra (2007) in "Widening Options in Access," article suggests some parameters to be considered by financing banks to SME sector as adequate cash flows, good means, sufficient collateral, good repayment record, purpose of loan, a post dealing with banks and FIs and quality of financial disclosure. The study points out that some of the enterprises are dealing with various banks and finding out new technology.

Raju (2008) in "Small and Medium Enterprises (SMEs) in India: Past, Present and Future," study concludes that SMEs have become the indispensible segment of economic growth in India and are entrepreneurs of Indian manufacturing sector. The study has discussed the constraints faced by SMEs in getting loans from the banks MSME Act 2006 have been examined to encourage this sector besides future policy parameters for sustainability of MSME sector

Ramcharan (2017) in his article "Financing Small and Medium Sized Enterprises in Thailand", has highlighted the need of bank credit to SMEs and mentioned that decline in SME financing requires efficient use of available funds and strategies to diversify by several measures of productivity of bank financing which includes prudent policies of the government, implementation of viable risk management techniques and approach to capital market training, export promotion and skilled labor along with awareness about the credit and various schemes. The viable sick units can be revived. 


\section{RESEARCH METHODOLOGY}

The present study focuses on finding financial challenges faced by MSME in raising credit from Banks at Bhopal district in Madhya Pradesh. This research study is of descriptive nature. In order to achieve the objective of this research study we will adopt both descriptive research and analytical research . The primary data has been collected through a questionnaire and personal discussion with owners, officials of the units financed by various financial institutions. Also the questionnaire was administered to 50 Branch Manager/Field Officers/Credit Officers of different banks dealing with MSME financing and main constraint observed by each of them has been analyzed.

\subsection{Sampling}

The selection of SME's is done through convenience sampling due to low response rate from these firms in pretesting, when chosen through random sampling. It includes both manufacturing and services firms. Sample of SME's is covering 200 entrepreneurs from Bhopal. Sample consists of sole proprietor, Partnership Limited Liability Partnership, Private Limited Company and 50 Branch Manager/Field Officers/Credit Officers of different banks dealing with MSME financing

\subsection{Primary Data}

We had framed a questionnaire based on the above studies. We have tried to raise all possible points through the questionnaire. It was designed in such a way that we will be able to identify key challenges faced by MSME in availing finance. Total of 200 MSME units and 50 Bank officials were selected for our study.

We also had one-to-one discussion with the Promoters of MSME units and had detailed discussion about key challenges in availing finance while filling up the questionnaires. We also welcomed any kind of feedback positive or negative from promoters of MSME units as well as their suggestions.

\subsection{Secondary Data}

Through various books, websites and literatures we have presented the whole survey in three forms:

- Bar diagrams

- Pie charts

- Tabular form

\subsection{Data Interpretation}

The finding which we have gathered from our survey has been represented in graphical form: 


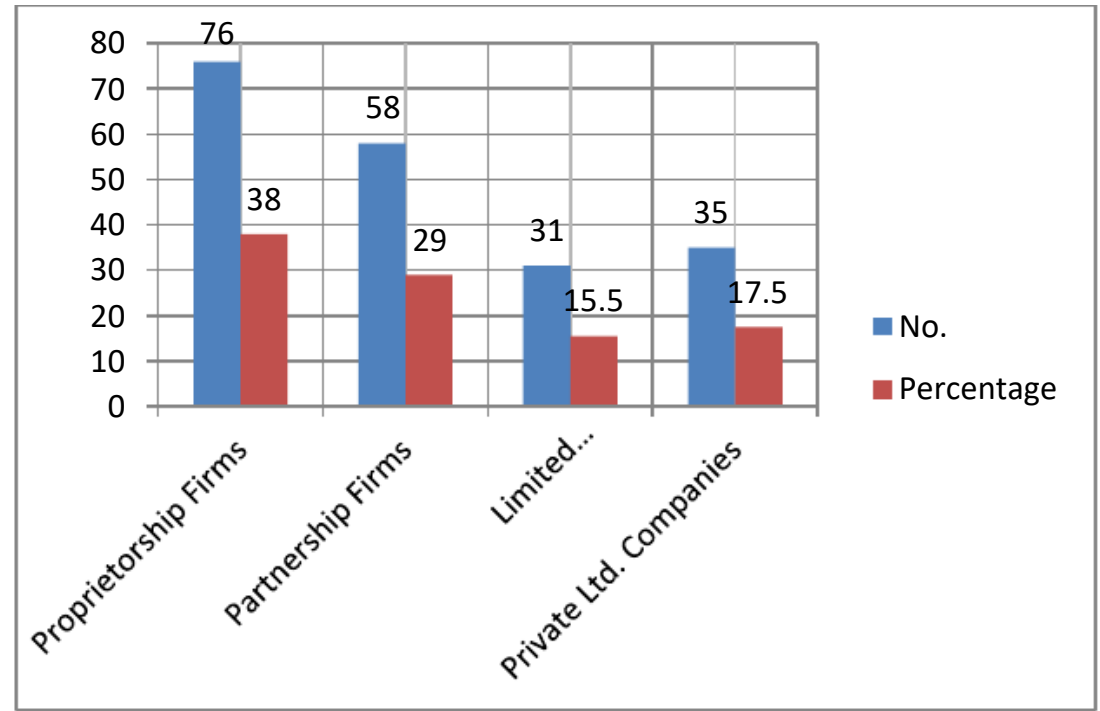

Figure 1 Type of Organization-Ownership Structure

Interpretation: According to this graph

- Out of these 200 respondents, $76(38 \%)$ respondents are proprietary firms

- $58(29 \%)$ respondents are partnership firms

- 31(15.50\%) respondents are Limited Liability Partnership

- $35(17.50 \%)$ respondents are Private Limited Companies

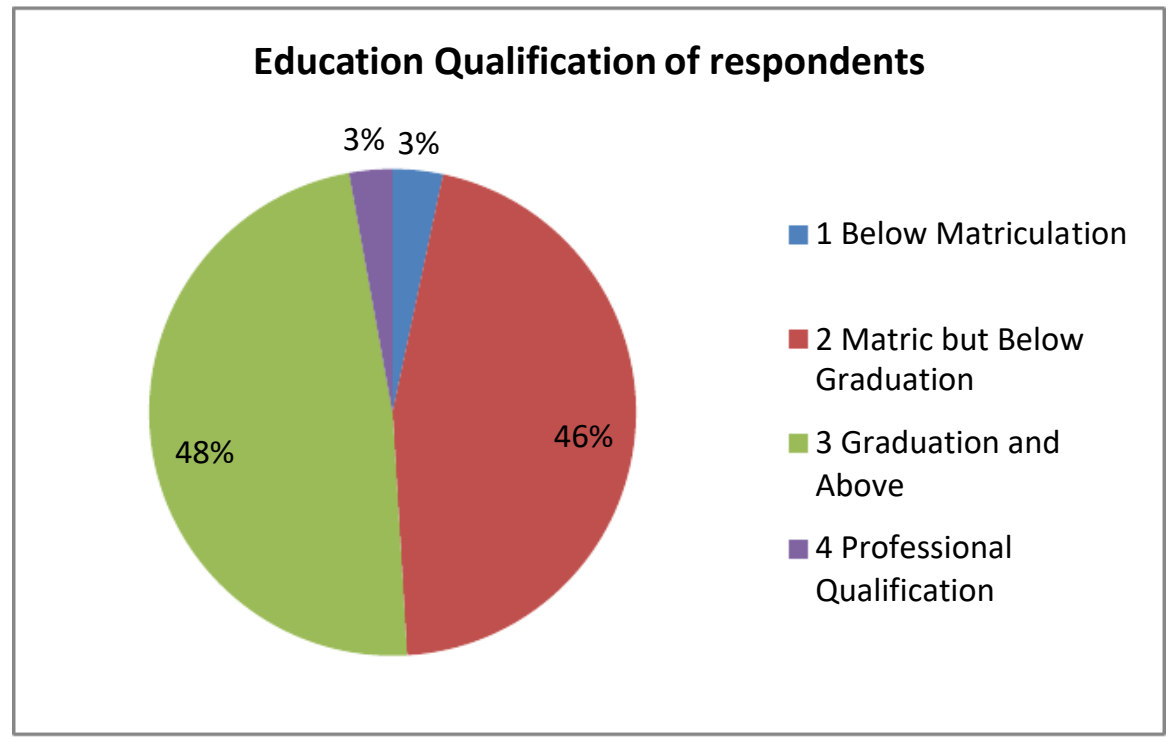

Figure 2 Education Qualification of respondents

Interpretation: According to this graph

- Only 6 respondents (3\%) are below Matriculation

- 96 respondents (48\%) are Metric but below Graduation

- 92 respondents (46\%) are Graduation and Above

- Only 6 respondents (3\%) are having Professional qualification

This reveals that most of the respondents are well qualified and could understand the procedural work and terms \& conditions of raising loans and could manage their business in a better way 


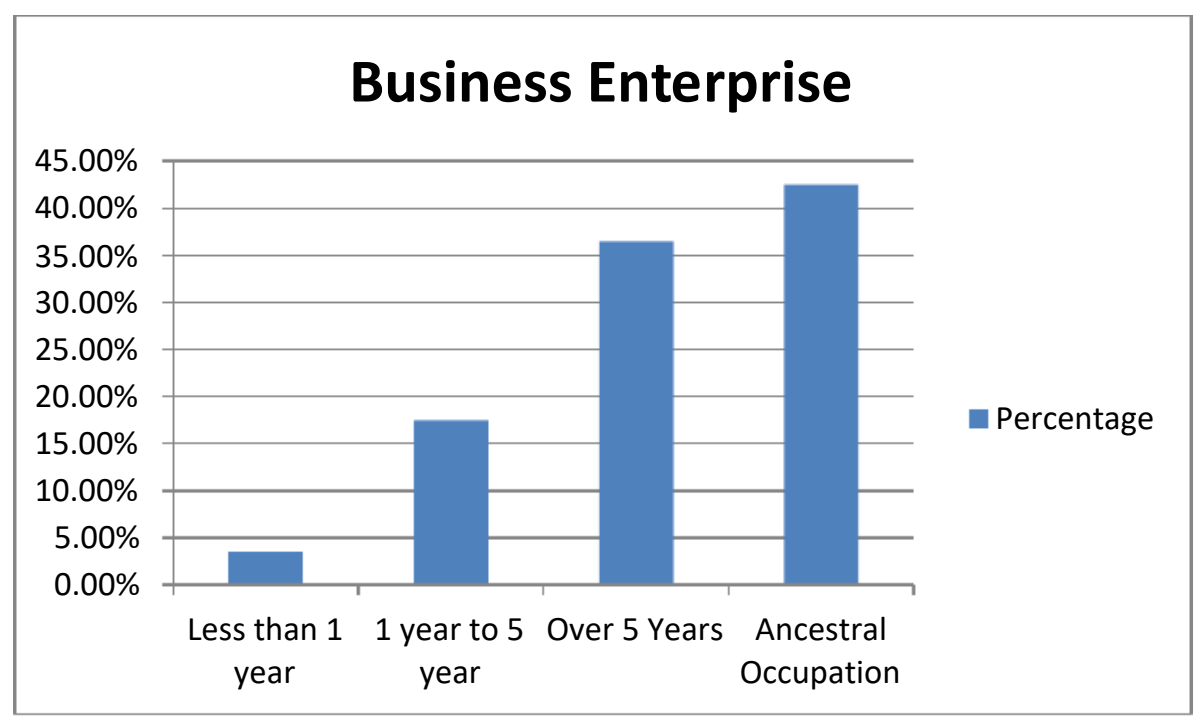

Figure 3 Distribution of Respondents (Enterprises) as per their Business Experience Interpretation: According to this graph

- Only 7 respondents (3.50\%) are having less than one year of Experience

- 35 respondents $(17.50 \%)$ are carrying the business for over one year to 5 years

- 73 respondents $(36.50 \%)$ are carrying business for over five years

- 85 respondents $(42.50 \%)$ are having ancestral occupation

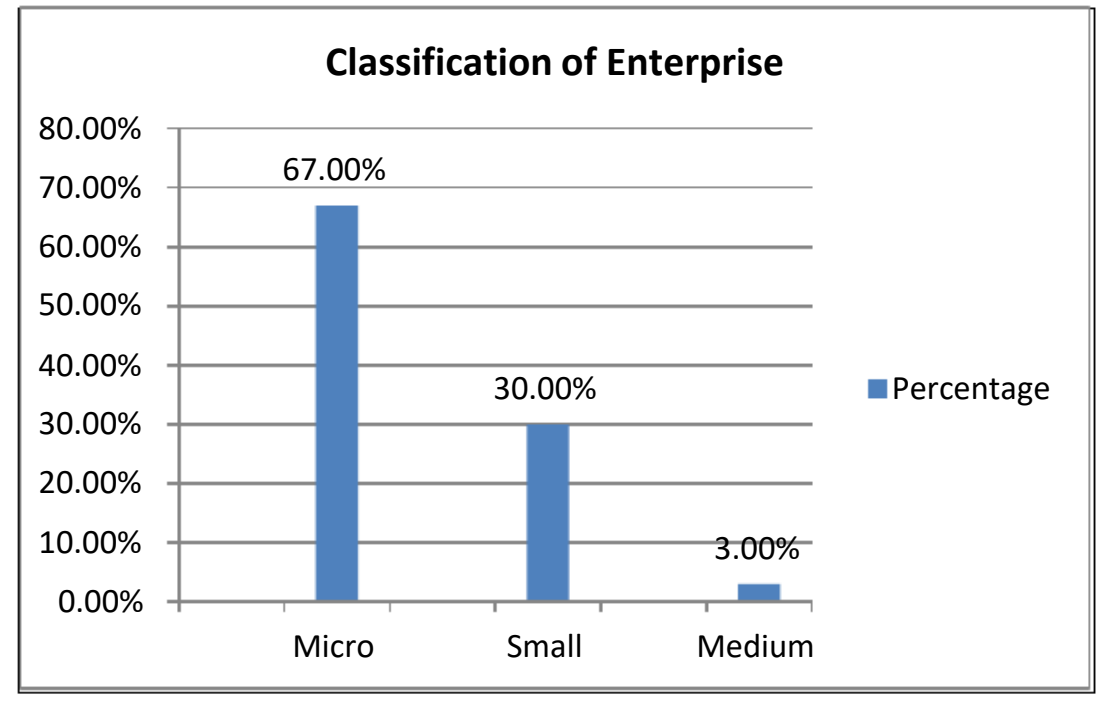

Figure 4 Classification of respondent enterprises on the basis of investment in plant and machinery Interpretation: This graph shows that

- Out of these 200 respondents, 134 (66.67\%) are Micro Enterprises,

- $60(30 \%)$ are Small Enterprises

- $6(3 \%)$ are Medium Enterprises.

Interpretation: This below graph shows that

- Out of these 200 respondents, 127 (63.50\%) are having turnover less than 1 Crore

- 66 respondents (33\%) are having turnover Rs. 1 Crore to Rs. 10 Crores

- 17 respondents $(8.50 \%)$ are having turnover more than 10 crores 


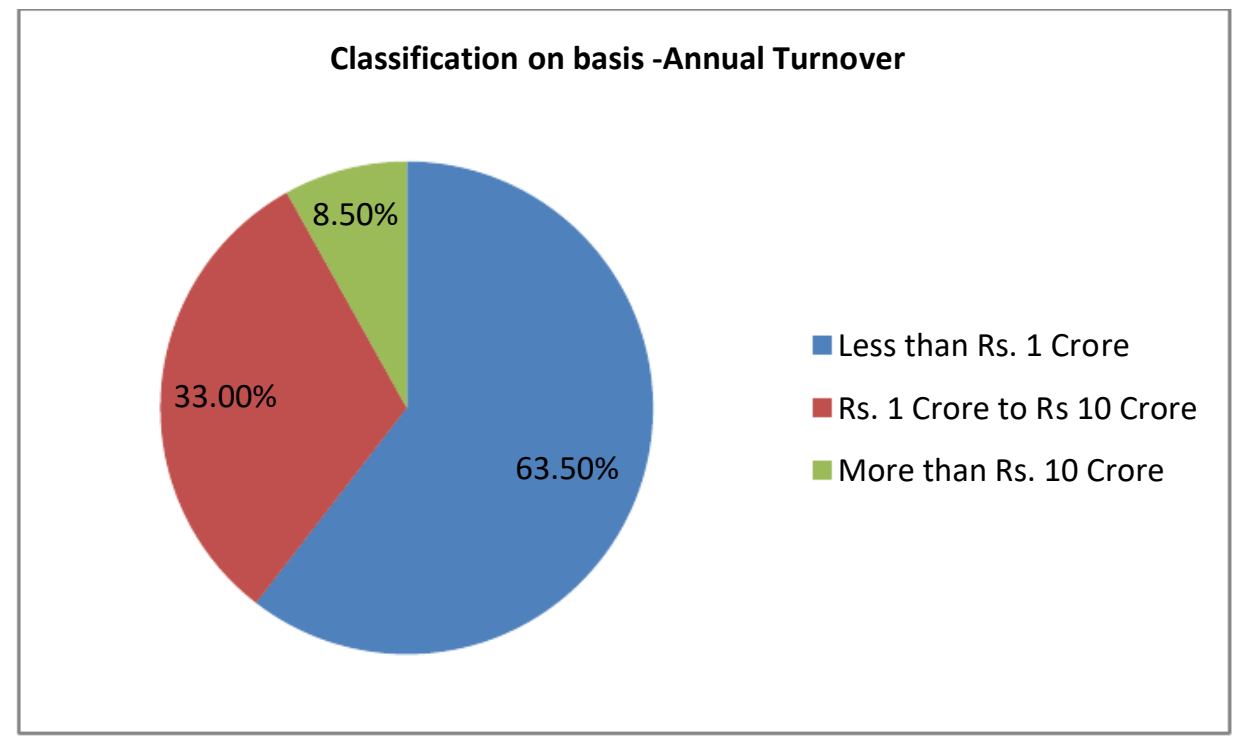

Figure 5 Classification of respondents according to past Annual Turnover of Business

Table 2 MSME Constraints -Respondent Viewpoint

\begin{tabular}{|c|c|c|c|c|}
\hline & Constraints & Total & \\
\hline Sr. No & (Respondents Point of view) & No. & Percentage & Rank \\
\hline 1 & Non availability of credit & 31 & $15.50 \%$ & 1 \\
\hline 2 & $\begin{array}{c}\text { Inadequate availability of } \\
\text { credit }\end{array}$ & 27 & $13.50 \%$ & 2 \\
\hline 3 & Delayed availability of credit & 25 & $12.50 \%$ & 3 \\
\hline 4 & complex Loan Process & 22 & $11 \%$ & 4 \\
\hline 5 & $\begin{array}{c}\text { Insist for Audit Balance sheet } \\
\text { and Financial Statement }\end{array}$ & 21 & $10.50 \%$ & 5 \\
\hline 6 & $\begin{array}{c}\text { High collateral security } \\
\text { approach }\end{array}$ & 19 & $7.13 \%$ & 6 \\
\hline 7 & $\begin{array}{c}\text { High rate of interest \& other } \\
\text { charges }\end{array}$ & 18 & $9.50 \%$ & 7 \\
\hline 8 & $\begin{array}{c}\text { Unco operative attitude of } \\
\text { Bankers }\end{array}$ & 15 & $7.50 \%$ & 8 \\
\hline 9 & $\begin{array}{c}\text { Redundant complaints } \\
\text { redressal, }\end{array}$ & 12 & $6 \%$ & 9 \\
\hline 10 & $\begin{array}{c}\text { Poor / marginal customer } \\
\text { services }\end{array}$ & 11 & $5.50 \%$ & 10 \\
\hline & Total & 200 & $100 \%$ & \\
\hline
\end{tabular}

Interpretation of constraints as per respondents views points

- Non availability of credit (Ranked 1) has been pointed out as the main constraint while accessing for bank loan by 31 respondents $(15.50 \%)$.

- Inadequate availability of credit: (Ranked 2) extended by banks to MSMEs has been pointed out by 27 respondents $(13.50 \%)$ as the main constraint.

- Delayed availability of credit: has been pointed out by 25 (12.50\%) respondents (Ranked 3) as main constraint.

- Complex Loan Process: (Ranked 4) has been pointed out by 22(11\%) respondents as main constraints

- Insist for Audit Balance sheet and Financial Statement: (Ranked 5) has been pointed by $21(10.50 \%)$ as main constraints 
- High Collateral Security Approach: (Ranked 6) has been pointed by $19(7.13 \%)$ as main constraints

- High rate of interest and other charges: (Ranked 7) is the main constraint revealed by $18(9.50 \%)$ of the MSME respondents.

- Unco operative attitude of Bankers: (Ranked 8) is the main constraint revealed by 15 (7.50\%) of the MSME respondents

- Redundant complaints redressal: (Ranked 9) is the main constraint revealed by $12(6 \%)$ of the MSME respondents

- Poor /Marginal Customer service (Ranked 10) is the main constraint revealed by 11 $(5.50 \%)$ of the MSME respondent

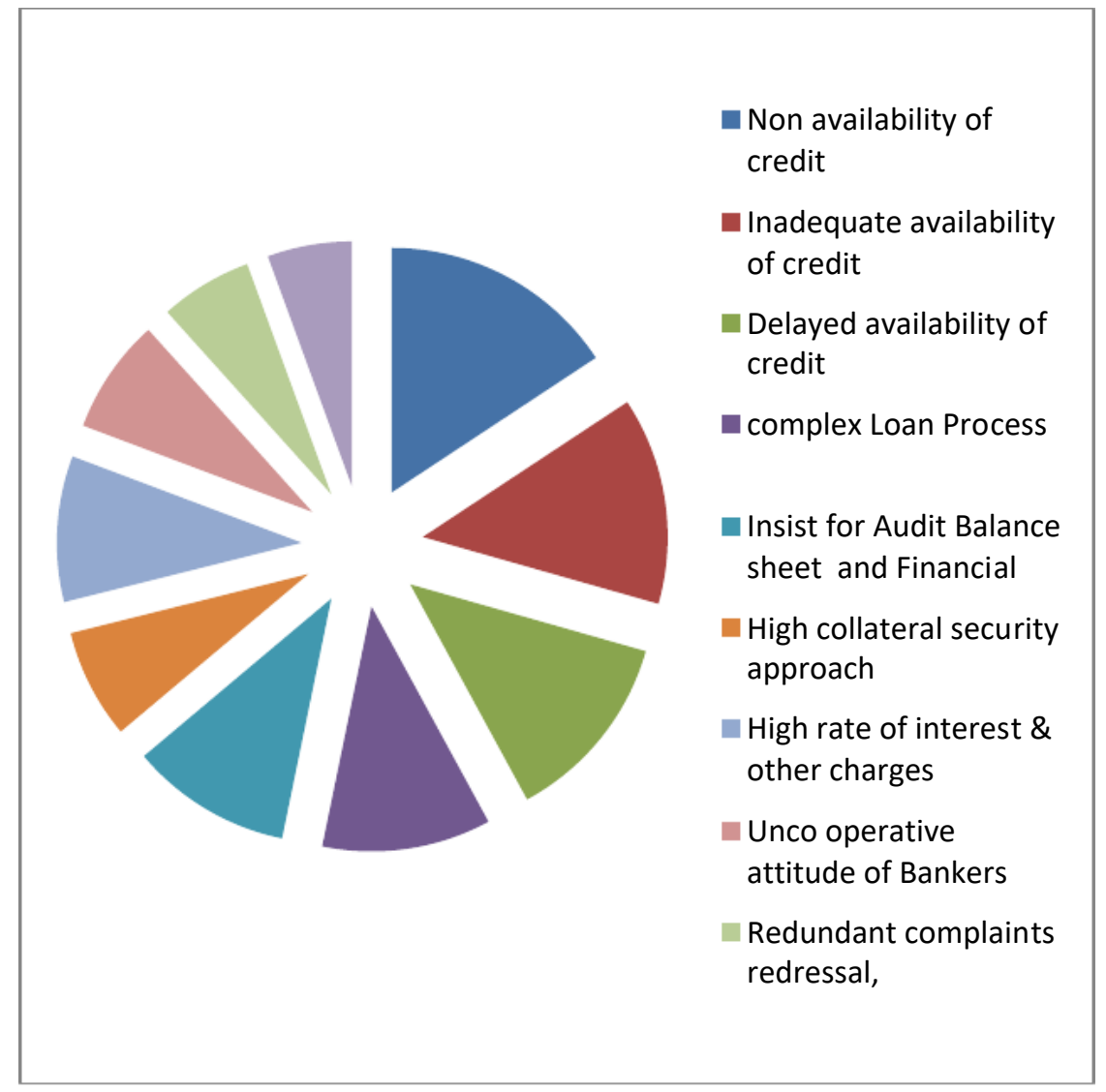

Figure 6

Interpretation of data (Constraints - Banker viewpoints)

- The biggest constraint as observed by the $14 \%$ of banker respondents ranked $1^{\text {st }}$ is the fear of staff accountability and fear of default and NPA.

- Mis- utilization of credit, diversion of funds, willful default and Higher lending risks/higher delinquency norms as the other constraints observed by $12 \%$ of Bank respondents all ranked $2^{\text {nd }}$.

- Non maintaining proper audited financial data and do not have/have low credit rating as the other constraints observed by $10 \%$ of Bank respondents all ranked 3rd.

- Poor repayment capacity/poor repay record and Fail to bring margin/own contribution as the other constraints observed by $8 \%$ of Bank respondents all ranked $4^{\text {th }}$.

- Low Net worth of customers and Marginal Managerial Capabilities of MSMEs as the other constraints observed by $6 \%$ of Bank respondents all ranked $5^{\text {th }}$ 
Table 3 Constraints in MSME financing (bank officials view points)

\begin{tabular}{|c|c|c|c|c|}
\hline $\begin{array}{c}\text { Sr. } \\
\text { No. }\end{array}$ & Constraints & Respondent & \% age & Rank \\
\hline 1 & Fear of staff accountability & 7 & $14 \%$ & 1 \\
\hline 2 & Fear of default and NPA & 7 & $14 \%$ & 1 \\
\hline 3 & $\begin{array}{c}\text { Mis- utilization of credit, } \\
\text { diversion of funds, willful } \\
\text { default }\end{array}$ & 6 & $12 \%$ & 2 \\
\hline 4 & $\begin{array}{c}\text { Higher lending risks/higher } \\
\text { delinquency norms }\end{array}$ & 6 & $12 \%$ & 2 \\
\hline 5 & $\begin{array}{c}\text { Non maintaining proper } \\
\text { audited financial data }\end{array}$ & 5 & $10 \%$ & 3 \\
\hline 6 & $\begin{array}{c}\text { Do not have/have low credit } \\
\text { rating }\end{array}$ & 5 & $10 \%$ & 3 \\
\hline 7 & $\begin{array}{c}\text { Poor repayment capacity/poor } \\
\text { repay record }\end{array}$ & 4 & $8 \%$ & 4 \\
\hline 8 & $\begin{array}{c}\text { Fail to bring margin/own } \\
\text { contribution }\end{array}$ & 4 & $8 \%$ & 4 \\
\hline 9 & Low Net worth of customers & 3 & $6 \%$ & 5 \\
\hline 10 & $\begin{array}{c}\text { Marginal Managerial } \\
\text { Capabilities of MSMEs }\end{array}$ & 3 & $6 \%$ & 5 \\
\hline & Total & 50 & 100 & 5 \\
\hline
\end{tabular}

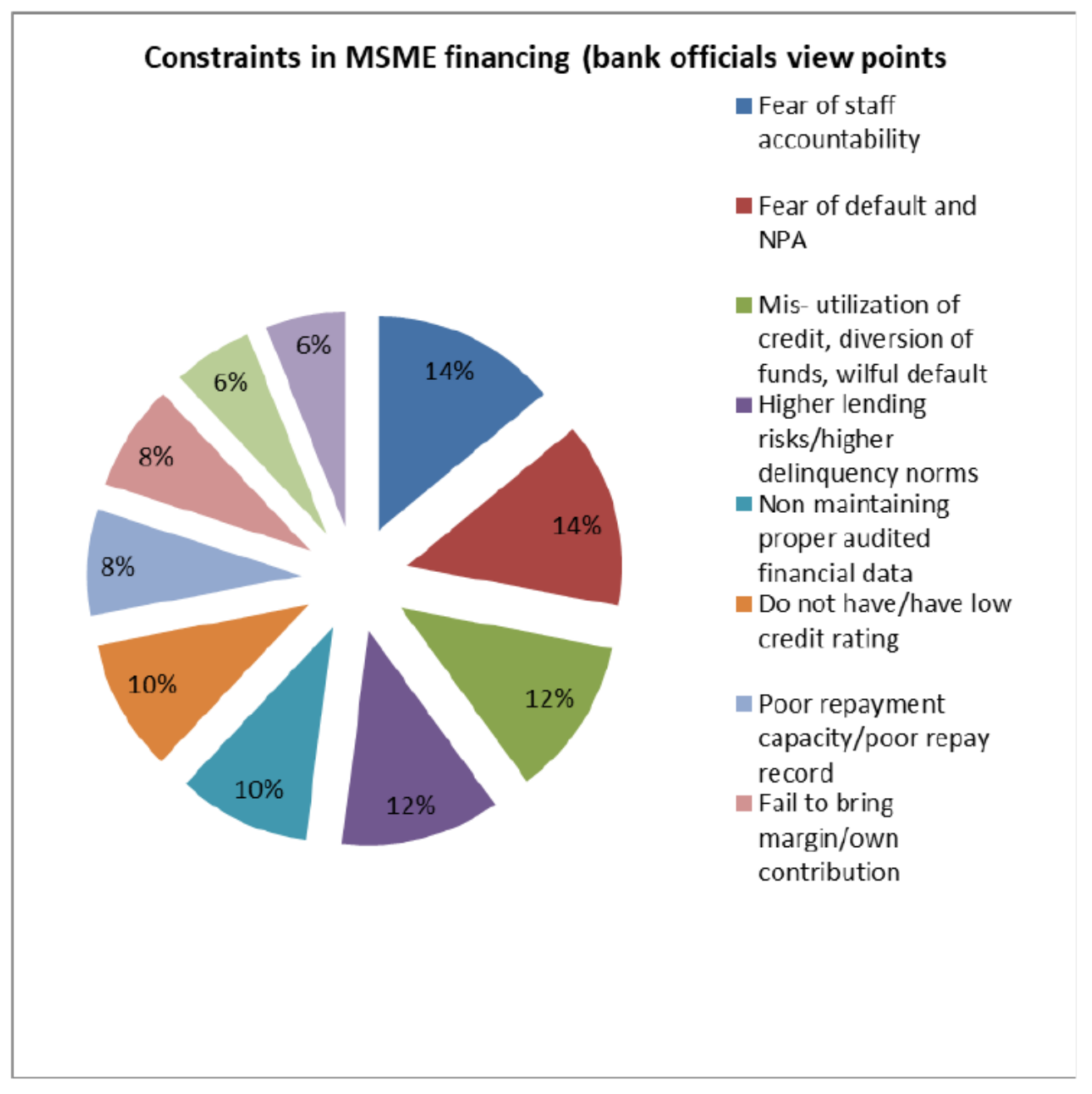

Figure 7 


\section{CONCLUSION}

On the basis of MSME Promoter Viewpoint: Summing up we can say that due to insufficient loan provided by banks and complex loan procedure and delays in sanctioning loan, MSMEs has to obtain loan from other sources like friends, relatives etc for meeting their financial needs. Firms find these sources convenient and easy to approach, as they do not require any complex paper work, collateral etc. It is suggested that the banks should not charge excessive interest rate and charges to MSMEs. The lengthy and cumbersome loan documents should be replaced by simple and easy bilingual documents. The borrowers should be in a position to understand the clauses of loan and its terms and conditions. The banks should have the proper complaints redressal mechanism and code of conduct for MSMEs. The banks should provide the excellent customer services with customer delight motto. The technical, financial and accounting guidance should be provided to the MSMEs by banks staff.

On the basis of Banker's Viewpoint: The bankers hesitate in extending finance to MSMEs with the fear of staff accountability on turning up the loans as NPA. The conventional and conservative staff accountability norms should be reviewed and relaxed in view of the present dynamic and understand its features with competitive business approach. The staff accountability in financing should be viewed on broader perspective, encouraging the bank credit extending staff to initiate proper, prompt and effective decisions. The staff accountability should be fixed in the cases involving frauds, malafides, considerations and gross negligence in adhering bank rules and regulations. Broader, conceptual, unbiased and circumstantial view should be taken while concluding disciplinary cases pertaining to NPAs. The margin money/own contribution norms should be relaxed in deserving cases. The audited balance sheets and financials should not be insisted from micro enterprises, the banks need to review and upgrade their technology. They should develop technology driven innovative products, services and schemes for MSMEs as per their taste and demand.

\section{REFERENCES}

[1] https://www.rbi.org.in

[2] https://msme.gov.in

[3] https://mpmsme.gov.in

[4] Small Industries Development Bank of India (SIDBI) Policy Paper Series, 2011

[5] Annual Report of Ministry of Micro, Small and Medium Enterprises

[6] Mohan, R. (2003) "Small-Scale Industry Policy in India: A Critical Evaluation.” In Economic Policy Reforms and the Indian Economy, ed. A.O. Krueger. New Delhi: Oxford University Press. 